\title{
Characterization of Petroleum Hydrocarbons in Post-Burn Crude Oil-Spilled Soils, Gokana, Rivers State, Nigeria
}

\section{*11MARK, O. ONYEMA; SAMUEL, E. OFODILE; LEO, C. OSUJI}

\author{
Petroleum and Environmental Geochemistry Research Group, \\ Department of Pure and Industrial Chemistry, University of Port Harcourt, \\ P.M.B 5323 Choba, Port Harcourt, 500001, Nigeria \\ *onyemark@yahoo.com
}

\begin{abstract}
In the Niger delta, crude oil spilled soils are burned as a means of decontaminating the impacted soils. Gas chromatography - flame ionization detector (GCFID) analyses were performed on oil residues extracted from burnt spilled oil soil samples to facilitate detailed chemical composition and characterization of petroleum hydrocarbons. The concentrations of aliphatic hydrocarbons (AHCs) from $\mathrm{C}_{13}$ to $\mathrm{C}_{36}$ were low and range from 363.4 to $439.6 \mathrm{mg} / \mathrm{kg}$, with hydrocarbons burning $\leq \mathrm{C}_{12}$ and the monocyclic aromatics BTEX not detected in all the samples. Polycyclic aromatic hydrocarbon (PAH) concentrations, which ranged from 3236.6 to $4190.0 \mathrm{mg} / \mathrm{kg}$, were significantly high and constituted from 88.26 to $91.25 \%$ of total petroleum hydrocarbon compositions in the burnt spilled oil soil samples. Petroleum hydrocarbon distribution profiles for the AHCs and PAHs were similar for all the samples and indicated similar alteration source. The compositions of AHCs were generally low, between 1.13 and $11.18 \%$, while compositions of PAHs varied considerably from 0.17 to $30.50 \%$. The composition of the 5-6 ring PAHs were between 3.94 - 4.65 times more than the 2-4 ring PAHs. From these results, the burning of spilled oil soils extensively degraded the AHCs and volatile low molecular weight aromatic hydrocarbons and generated significant amounts of 5-6 ring PAHs, some of which are carcinogenic. (C) JASEM
\end{abstract}

\section{http://dx.doi.org/10.4314/jasem.v19i4.20}

\section{Introduction}

The characterization of petroleum hydrocarbons in soils and water at environmental release sites is important for environmental damage assessment (Stout et. al., 2007). When crude oil spills, via equipment failure, operational mishap and/or intentional damage to oil production facilities, petroleum hydrocarbons are released into the environment. The fate of these petroleum hydrocarbons depend on the processes which act on the spilled oil to reduce its concentration and alter the chemical composition (Hostettler and Kvenvolden, 1994; Wang et. al., 1998).

Studies on oil spill, by geochemists and analytical chemists, have focused on the characterization of petroleum hydrocarbon components - saturate hydrocarbons: $n$-alkanes from $\mathrm{C}_{8}-\mathrm{C}_{40}$, isoprenoids pristane and phytane, and biomarker compounds terpanes and steranes; the volatile monocyclic aromatic compounds: benzene, toluene, ethylbenzene, and xylene isomers (BTEX) and alkylated benzene compounds; and polycyclic aromatic hydrocarbon (PAH) compounds (Munoz et. al., 1997; Christensen and Tomasi, 2007). Most frequently, environmental forensic investigations of oil spills use gas chromatography equipped with flame ionization detector (GC-FID) or mass spectrometry (GC-MS) to facilitate the detailed compositional analysis of petroleum hydrocarbons (Wang and Fingas, 2003). These systems generate data on petroleum hydrocarbons which are used to identify the type of oil spilled, quantify and characterize the chemical composition of the petroleum hydrocarbon compounds in the spilled site, reveal petroleum hydrocarbon contamination source and characterize all petroleum hydrocarbons in the environment for spill source identification, oil correlation and differentiation (Barakat et. al., 2002; Oros et. al., 2007; Sun et. al., 2009).

The Niger delta region of southern Nigeria is the country's hub of oil and gas. The region is also highly blessed with fertile agricultural land, aquatic resources, wild life and palm oil, thus, the natives are predominantly farmers and fishers. The presence of oil wells, flow stations and numerous pipelines that criss-cross the land and seascape of communities in the Niger delta renders the region vulnerable to oil spills (Zabbey, 2008). The continuous use of these facilities, over the past 50 years, has resulted in a spate of burst pipelines and the discharge of millions of barrels of oil into the land, swamps, estuaries and coastal waters (Dublin-Green et. al., 1998). Consequently, the cause of oil spills are usually attributed to equipment failure on the part of the operating oil companies, who on the other hand, allege acts of sabotage. Although clean up measures are usually carried out, in some cases, as part of oil spill contingency programme, polluted environments are sometimes neglected to the slow process of natural attenuation (Osuji et. al., 2006; Hart et. al., 
2007). Some natives, as part of reclaiming their lands for farming activities, burn the oil spilled site. Though, thought of as a means of decontaminating the impacted soils by removing the spilled oil via burning, the chemical implication has been neglected. Evaluating the impact of burning on spilled oil soils is site specific, thus we focused our attention on the detailed chemical composition characterization of petroleum hydrocarbons by GC-FID analysis.

\section{MATERIALS AND METHODS}

Sampling site description and collection The study site is located at Gokana $\left(4^{\circ} 39^{\prime} \mathrm{N}, 7^{\circ} 16^{\prime} \mathrm{E}\right)$ in Rivers State, Niger Delta, southern Nigeria. Sampling was carried out at a section of the spilled crude oil farmland which was burnt (fig. 1). Soil samples were collected at four (4) points of the burnt site at surface depth $(0-10 \mathrm{~cm})$ using a stainless steel scoop. The samples were packed in pre-cleaned glass jars, labelled appropriately, transported to the laboratory and stored at room temperature until analysis.

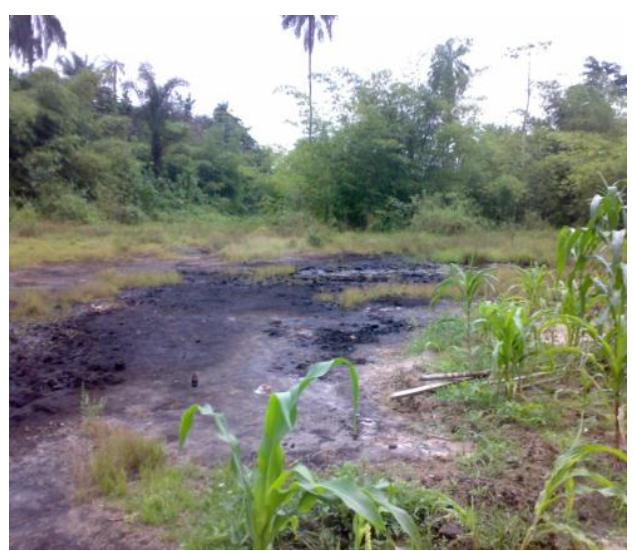

Fig 1: Photograph of a section of a post-burn crude oil spilled farmland.

Petroleum hydrocarbon extraction and fractionation The burnt spilled oil soil samples were air dried at room temperature, homogenized by hand mixing and foreign objects such as rocks, leaves, sticks etc. were removed. The soil samples were soxhlet-extracted with hexane/dichloromethane mixture (1:3). The extracted oil residues were concentrated, allowed to cool and fractionated by transferring onto the top of a glass chromatographic column $(30 \mathrm{~cm} \times 1 \mathrm{~cm})$ plugged with glass wool at the base and packed with activated silica. $n$-hexane was used to elute the saturate hydrocarbons and dichloromethane was used to elute the aromatic hydrocarbons. The two fractions were concentrated by evaporating the solvents at room temperature in the laboratory.
Gas chromatographic (GC) analysis: Gas chromatography (GC) was performed using a Hewlett Packard (HP) system 6890 series fitted with a fused silica capillary column $(30 \mathrm{~m} \times 0.25 \mathrm{~mm})$, equipped with a flame ionization detector (FID) and a split/splitless injector. Helium was used as the carrier gas. The concentrated saturate and aromatic fractions were transferred into labelled vials and $1 \mu \mathrm{L}$ injected into the GC system with the aid of an automatic liquid sampler. Oven temperature for aliphatic hydrocarbon analysis was programmed from $70^{\circ} \mathrm{C}$ to $320^{\circ} \mathrm{C}$ at $4^{\circ} \mathrm{C} / \mathrm{min}$ with a 20 mins hold at $320^{\circ} \mathrm{C}$, while for polycyclic aromatic hydrocarbons analysis, from $50^{\circ} \mathrm{C}$ to $300^{\circ} \mathrm{C}$ at $10^{\circ} \mathrm{C} / \mathrm{min}$ with a 2 min hold at $50^{\circ} \mathrm{C}$ and a $10 \mathrm{mins}$ hold at $300^{\circ} \mathrm{C}$. Compound peaks identification was based on retention times compared to standards and quantification acquired by Agilent's chemstation software.

\section{RESULTS AND DISCUSSION}

Petroleum hydrocarbon analyses: Petroleum hydrocarbons identified by gas chromatographic analyses of oil residues, extracted from the burnt spilled-oil soil samples, were aliphatic hydrocarbons (AHCs) and polycyclic aromatic hydrocarbons (PAHs), with no detectable amount of the monocyclic aromatic component - benzene, toluene, ethylbenzene, xylene isomers and alkylated benzenes (BTEX). The BTEX hydrocarbons are volatile and consequently, their absence in the spilled-oil soils attributed to burning. Assessment of petroleum hydrocarbon components showed total AHC concentrations were low and range from 363.39 $439.55 \mathrm{mg} / \mathrm{kg}$ (table 1), while total PAH concentrations were very high and range from 3236.64 - $4189.98 \mathrm{mg} / \mathrm{kg}$ (table 2). These concentrations constitute from 8.75 to $11.74 \%$ and 88.26 to $91.25 \%$ of total petroleum hydrocarbon compositions respectively. AHCs are the predominant group of petroleum hydrocarbons in crude oils (Tissot and Welte, 1984). However, their abundance in the spilled-oil soils were significantly reduced, in contrast with their compositions in crude oils. This indicate extensive degradation of the AHC component of the spilled crude oil by burning.

Aliphatic hydrocarbons: Analysis of the saturate hydrocarbon fraction of the oil residues, extracted from the burnt spilled oil soils, identified aliphatic hydrocarbons (AHCs) from $n \mathrm{C}_{13}$ to $n \mathrm{C}_{36}$ including pristane $(\mathrm{Pr})$ and phytane $(\mathrm{Ph})$. The concentrations of AHCs identified in the burnt spilled oil soil samples are listed in Table 1. 
Table 1: Concentrations of aliphatic hydrocarbons (AHCs) in the burnt spilled oil soil samples (mg/kg).

\begin{tabular}{|c|c|c|c|c|}
\hline Compound & Sample 1 & Sample 2 & Sample 3 & Sample 4 \\
\hline $\mathrm{C}_{13}$ & 8.2 & 10.4 & 7.8 & 10.8 \\
\hline $\mathrm{C}_{14}$ & 9.1 & 10.2 & 8.1 & 8.9 \\
\hline $\mathrm{C}_{15}$ & 9.9 & 9.2 & 9.3 & 9.9 \\
\hline $\mathrm{C}_{16}$ & 12.4 & 11.4 & 9.9 & 10.3 \\
\hline $\mathrm{C}_{17}$ & 13.4 & 11.6 & 12.4 & 11.1 \\
\hline $\operatorname{Pr}$ & 13.0 & 11.1 & 13.0 & 11.7 \\
\hline $\mathrm{C}_{18}$ & 9.6 & 10.0 & 9.6 & 10.4 \\
\hline $\mathrm{Ph}$ & 10.8 & 10.9 & 10.8 & 11.6 \\
\hline $\mathrm{C}_{19}$ & 12.7 & 18.5 & 12.7 & 13.2 \\
\hline $\mathrm{C}_{20}$ & 11.4 & 14.3 & 11.4 & 12.3 \\
\hline $\mathrm{C}_{21}$ & 12.0 & 16.1 & 12.0 & 12.9 \\
\hline $\mathrm{C}_{22}$ & 12.5 & 14.0 & 12.5 & 14.2 \\
\hline $\mathrm{C}_{23}$ & 9.9 & 10.8 & 9.9 & 11.9 \\
\hline $\mathrm{C}_{24}$ & 11.1 & 11.5 & 11.1 & 12.4 \\
\hline $\mathrm{C}_{25}$ & 7.9 & 10.7 & 7.9 & 9.8 \\
\hline $\mathrm{C}_{26}$ & 20.0 & 12.7 & 9.2 & 16.1 \\
\hline $\mathrm{C}_{27}$ & 16.4 & 17.0 & 16.4 & 19.3 \\
\hline $\mathrm{C}_{28}$ & 38.8 & 42.0 & 38.8 & 49.1 \\
\hline $\mathrm{C}_{29}$ & 23.3 & 29.8 & 23.3 & 30.6 \\
\hline $\mathrm{C}_{30}$ & 24.5 & 22.9 & 24.4 & 35.7 \\
\hline $\mathrm{C}_{31}$ & 19.1 & 31.9 & 18.9 & 20.9 \\
\hline $\mathrm{C}_{32}$ & 17.1 & 19.0 & 23.2 & 24.9 \\
\hline $\mathrm{C}_{33}$ & 14.7 & 24.4 & 37.0 & 22.6 \\
\hline $\mathrm{C}_{34}$ & 11.8 & 31.7 & 36.6 & 27.5 \\
\hline $\mathrm{C}_{35}$ & 9.1 & 10.9 & 8.9 & 16.4 \\
\hline $\mathrm{C}_{36}$ & 4.6 & 7.6 & 6.8 & 5.0 \\
\hline Total AHC & 363.4 & 430.5 & 401.9 & 439.6 \\
\hline
\end{tabular}

From table 1, aliphatic hydrocarbons up to $\mathrm{C}_{12}$ were not detected in the samples, while the concentrations of $\mathrm{C}_{13}$ to $\mathrm{C}_{36}$ hydrocarbons were low. The concentrations of aliphatic hydrocarbons from $\mathrm{C}_{13}$ to $\mathrm{C}_{25}$, including pristane and phytane, were very low with $\mathrm{C}_{13}$ from 7.8 to $10.8 \mathrm{mg} / \mathrm{kg}$ (mean of $9.3 \pm 1.5$ $\mathrm{mg} / \mathrm{kg}$ ), $\mathrm{C}_{14}$ from 8.1 to $10.2 \mathrm{mg} / \mathrm{kg}$ (mean of $9.1 \pm 0.8$ $\mathrm{mg} / \mathrm{kg}$ ), and $\mathrm{C}_{15}$ from 9.2 to $9.9 \mathrm{mg} / \mathrm{kg}$ (mean of $9.6 \pm 0.4 \mathrm{mg} / \mathrm{kg}$ ) being among the least abundant (table 1). The most abundant aliphatic hydrocarbons was $\mathrm{C}_{28}$ from 38.8 to $49.1 \mathrm{mg} / \mathrm{kg}$ (mean of $42.2 \pm 4.9$ $\mathrm{mg} / \mathrm{kg}$ ) followed by $\mathrm{C}_{30}$ from 22.9 to $35.7 \mathrm{mg} / \mathrm{kg}$ (mean of $26.9 \pm 5.9 \mathrm{mg} / \mathrm{kg}$ ). These hydrocarbons, as well as other hydrocarbons from $\mathrm{C}_{26}$ to $\mathrm{C}_{34}$, showed slightly higher concentrations in all the samples (table $1)$. The distribution of $n$-alkanes and isoprenoids are used for characterization in oil spill studies and serve as indicator of the degree of degradation of resolved aliphatic hydrocarbons (Peters et. al., 2005; Onyema et. al., 2013). Niger Delta crude oils are typically light $\left(35^{\circ}\right.$ API or higher) and show aliphatic hydrocarbon abundance in the low molecular weight hydrocarbon range (up to $\mathrm{C}_{20}$ ) with pristane usually prominent and dominant over phytane (Manilla and Onyema, 2008). The complete absence of hydrocarbons boiling below $\mathrm{C}_{12}\left(\leq 240^{\circ} \mathrm{C}\right)$ and the substantially reduced amounts of the low molecular weight aliphatic hydrocarbons, including pristane and phytane, indicate extensive degradation of the aliphatic hydrocarbons by burning.

Polycyclic aromatic hydrocarbon (PAH) Aromatic hydrocarbons identified in the burnt spilled oil soils, by chromatographic analysis of the residual oil, are parent polycyclic aromatic hydrocarbons (PAHs) with 2 to 6 fused aromatic rings together. The concentrations of the parent PAH compounds are listed in Table 2. PAH concentrations in the burnt spilled oil soils ranged from 3236.6 to $4190.0 \mathrm{mg} / \mathrm{kg}$ with an average of $3586.4 \pm 614.3 \mathrm{mg} / \mathrm{kg}$ (table 2). 
Table 2: Concentrations of polycyclic aromatic hydrocarbons (PAHs) in the burnt spilled oil soil samples $(\mathrm{mg} / \mathrm{kg}$ ).

\begin{tabular}{|c|c|c|c|c|c|}
\hline & PAH Compound & $\begin{array}{r}\text { Sample } \\
1\end{array}$ & $\begin{array}{r}\text { Sample } \\
2\end{array}$ & $\begin{array}{r}\text { Sample } \\
3\end{array}$ & $\begin{array}{r}\text { Sample } \\
4\end{array}$ \\
\hline \multirow{10}{*}{$\begin{array}{c}2 \\
\text { rings } \\
\text { to } \\
4 \\
\text { rings }\end{array}$} & Naphthalene (Nap) & 85.8 & 85.8 & 94.3 & 85.8 \\
\hline & Acenaphthylene (Acy) & 145.8 & 117.6 & 156.2 & 131.7 \\
\hline & Acenaphthene (Ace) & 36.0 & 56.8 & 51.3 & 46.4 \\
\hline & Fluorene (Fle) & 53.9 & 56.7 & 55.6 & 55.3 \\
\hline & Phenanthrene (Phe) & 39.5 & 21.6 & 34.1 & 30.6 \\
\hline & Anthracene (Ant) & 28.6 & 17.6 & 38.7 & 23.1 \\
\hline & Fluoranthene (Fth) & 196.6 & 127.4 & 279.8 & 162.0 \\
\hline & Pyrene (Pyr) & 69.8 & 64.3 & 90.6 & 67.1 \\
\hline & $\begin{array}{l}\text { Benzo }(\alpha) \text { anthracene } \\
(\mathrm{BaA})\end{array}$ & 6.2 & 10.6 & 20.2 & 12.3 \\
\hline & Chrysene (Chr) & 7.8 & 14.0 & 26.9 & 12.1 \\
\hline \multirow{10}{*}{$\begin{array}{c}5 \\
\text { ring } \\
\text { to } \\
6 \\
\text { ring }\end{array}$} & $\begin{array}{l}\text { Benzo(b)fluoranthene } \\
\text { (BbF) }\end{array}$ & 140.4 & 219.0 & 335.1 & 179.7 \\
\hline & $\begin{array}{l}\text { Benzo(k)fluoranthene } \\
(\mathrm{BkF})\end{array}$ & 166.8 & 90.3 & 255.9 & 128.6 \\
\hline & Benzo(e)pyrene (BeP) & 112.4 & 235.3 & 323.8 & 173.9 \\
\hline & Benzo(a)pyrene (BaP) & 245.4 & 273.8 & 196.7 & 259.6 \\
\hline & $\begin{array}{l}\text { Indeno(1,2,3-cd)pyrene } \\
\text { (IP) }\end{array}$ & 929.3 & 942.4 & 919.8 & 935.9 \\
\hline & $\begin{array}{l}\text { Dibenzo(a,h)anthracene } \\
\text { (DA) }\end{array}$ & 1076.7 & 734.9 & 1108.4 & 905.8 \\
\hline & $\begin{array}{l}\text { Benzo(g,h,i)perylene } \\
(\mathrm{BP})\end{array}$ & 189.1 & 168.5 & 202.7 & 178.8 \\
\hline & Total PAH & 3530.3 & 3236.6 & 4190.0 & 3388.6 \\
\hline & $\Sigma 2$ - 4 ring $\mathrm{PAH}$ & 670.1 & 572.5 & 847.7 & 626.4 \\
\hline & $\Sigma 5$ - 6 ring PAH & 2860.2 & 2664.1 & 3342.3 & 2762.2 \\
\hline
\end{tabular}

Total PAH concentration in the burnt spilled oil soils were high (table 2) and twice more than the concentration of $1541.6 \mathrm{mg} / \mathrm{kg}$ measured for Niger Delta crude oil (Onyema, 2012). This indicated that though the spilled crude oil caused pollution of the soils by PAH, burning substantially increased the amounts.

From table 2, the 5-6 ring PAHs had high concentrations, with DA from 734.9 to $1108.4 \mathrm{mg} / \mathrm{kg}$ (mean of $956.4 \mathrm{mg} / \mathrm{kg}$ ), IP from 919.8 to $942.4 \mathrm{mg} / \mathrm{kg}$ (mean of $931.8 \mathrm{mg} / \mathrm{kg}$ ) and $\mathrm{BaP}$ from 196.7 to 273.8 $\mathrm{mg} / \mathrm{kg}$ (mean of $243.9 \mathrm{mg} / \mathrm{kg}$ ) being the most abundant respectively. The concentrations of 2-4 ring PAHs were low, with BaA from 6.2 to $20.2 \mathrm{mg} / \mathrm{kg}$ (mean of $12.3 \mathrm{mg} / \mathrm{kg}$ ), Chr from 7.8 to $26.9 \mathrm{mg} / \mathrm{kg}$ (mean of $15.2 \mathrm{mg} / \mathrm{kg}$ ) and Ant from 17.6 to 38.7 $\mathrm{mg} / \mathrm{kg}$ (mean of $27.0 \mathrm{mg} / \mathrm{kg}$ ) being the least abundant, while the 1-ring aromatic hydrocarbons were not detected. Crude oils are mostly dominated by the low molecular weight (LMW) PAHs with the high molecular weight (HMW) PAHs present at low concentrations (Wang et. al., 2006). The total concentrations of the 5-6 ring PAHs in the burnt spilled oil soil samples were observed to be between 3.94 - 4.65 times more than the 2-4 ring PAHs (table 2 ). The dominance of the 5-6 ring over 2-4 ring and the absence of the 1-ring aromatic hydrocarbons indicate that the burning of the spilled oil soils degraded the volatile LMW aromatic hydrocarbons and substantially increased the HMW PAHs, some of which are known carcinogens.

Profile of petroleum hydrocarbon: Compositional analyses of data generated from GC-FID were performed to facilitate the characterization of petroleum hydrocarbons (AHCs and PAHs) in the burnt spilled oil soils. The compositional profile of AHC and PAH distribution patterns in the burnt spilled oil soil samples are shown if fig 2 . and 3 respectively.

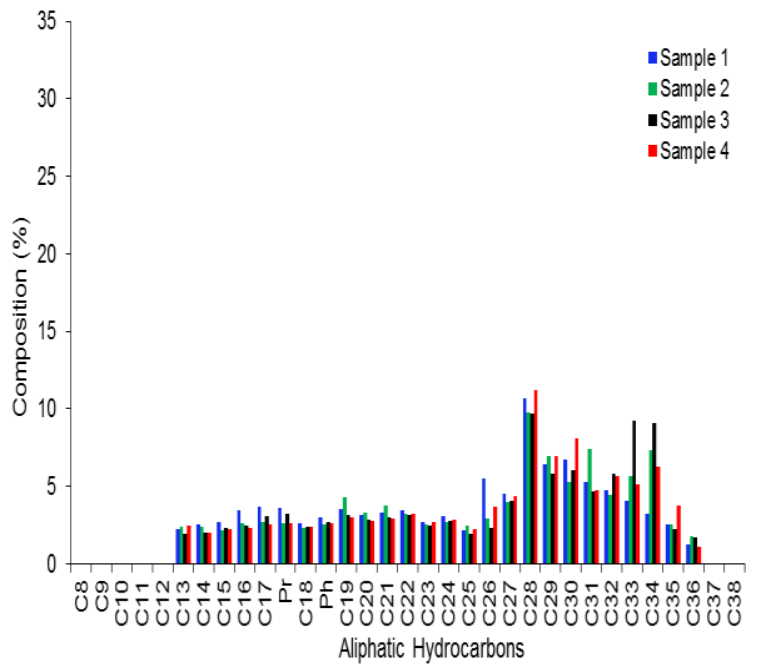

Fig 2: Compositional distribution of aliphatic hydrocarbons in the burnt spilled oil soils. 
It was observed from the distribution profile that variations in composition among individual petroleum hydrocarbons (AHCs; fig. 2 and PAHs; fig. 3) followed similar pattern for all the samples. Compositional profile of petroleum hydrocarbon distribution are used for distinguishing hydrocarbon input in contaminated environments as well as information on their attenuation (Olajire Abbas and Brack, 2005).

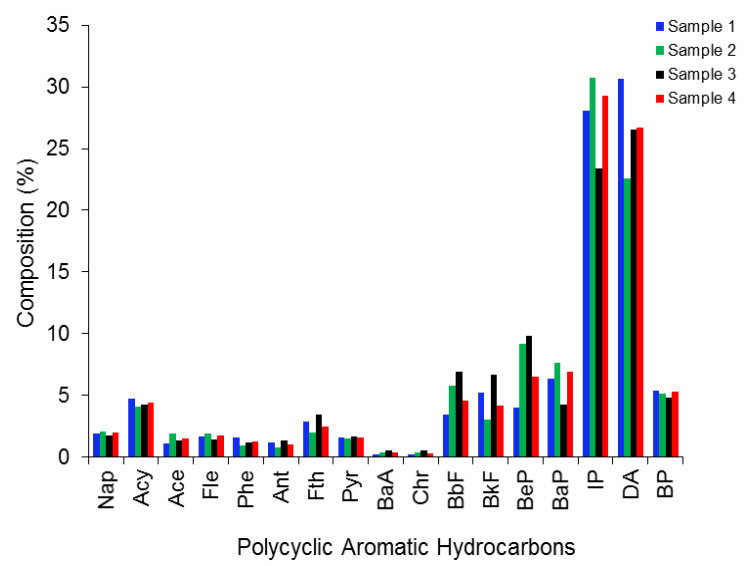

Fig 3: Compositional distribution of polycyclic aromatic hydrocarbons in the burnt spilled oil soils.

The similar profile pattern observed for all the samples suggest same process of attenuation for petroleum hydrocarbons in the spilled oil soils. The composition of AHCs were generally low and range from $1.13-11.18 \%$, while the composition of PAHs varied considerably from $0.17-30.50 \%$. Petroleum hydrocarbon compositions in all the samples were dominated by 5 and 6 ring HMW PAHs: DA $\left(\mathrm{C}_{22} \mathrm{H}_{14}\right)$ accounting for $22.71-30.50 \%$, and IP $\left(\mathrm{C}_{22} \mathrm{H}_{12}\right)$ accounting for $21.95-29.12 \%$ of total PAH in the burnt oil spill soil samples (fig. 2). This compositional feature of petroleum hydrocarbon distribution pattern in the burnt spill oil soils indicate the removal of AHCs and LMW PAHs and increase of 5 and 6 ring HMW PAHs by burning.

Conclusion: The characterization of petroleum hydrocarbons in burnt spilled oil soil samples revealed the presence of aliphatic hydrocarbons and polycyclic aromatic hydrocarbons. Aliphatic hydrocarbon concentrations were generally low with the loss of hydrocarbons boiling below $\mathrm{C}_{12}$. Polycyclic aromatic hydrocarbon (PAH) concentrations varied considerably. High concentrations of the $5-6$ ring PAHs, which was between $3.94-4.65$ times more than the $2-4$ ring PAHs, dominated petroleum hydrocarbon compositions in all the samples. This extensive degradation of the aliphatic hydrocarbons and volatile low molecular weight PAHs, with the substantial increase of carcinogenic high molecular weight PAHs was the consequence of burning the spilled oil soils.

\section{REFERENCES}

Barakat, A. O., Qian, Y., Kim, M., Kennicutt II, M. C. (2002). Compositional changes of aromatic steroid hydrocarbons in naturally weathered oil residues in Egyptian Western Desert. Environmental Forensics 3: 219-226.

Christensen, J. H., Tomasi G. (2007). A multivariate approach to oil hydrocarbon fingerprinting and spill source identification. Oil Spill Environmental Forensics pp 293-325.

Dublin-Green, W.F., Nwankwo, J.N., Irechukwu, D.O. (1998). Effective regulation and management of HSE issues in the petroleum industry. SPE International Conference on Health, Safety and Environment in oil and gas exploration and production, Caracas, Venezeula, 7 - 10 June, 1998. paper No. SPE $40 / 26$.

Hart, A.I., Amah, E., Zabbey, N. (2007). Biocenosis of planktonic flora in a 36 years old crude oil polluted freshwater pond in the Niger Delta, Nigeria. African Journal of Zoology and Environmental Biology 9: 63-69.

Hostettler, F.D., Kvenvolden, K.A. (1994). Geochemical Changes in Crude Oil Spilled from the Exxon Valdez Supertanker into Prince William Sound, Alaska. Organic Geochemistry 21: 927-936

Manilla, P.N., Onyema, O.M. (2008). Correlation of some crude oils using low molecular weight geochemical markers: A case study of the Niger Delta. Journal of Chemical Society of Nigeria 33: 225-234.

Munoz, D., Guiliano, M., Doumenq, P., Jacquot, F., Scherrer, P., Mille, G. (1997). Long term evolution of petroleum biomarkers in mangrove soil. Marine Pollution Bulletin 34: 868-874.

Olajire Abbas, A., Brack, W. (2005). Polycyclic aromatic hydrocarbons in Niger Delta soil: contamination sources and profiles. International Journal of Environmental Science and Technology 2(4): 343-352.

Onyema M.O., Osuji L.C., Ilechukwu, I. P. (2013). Assessment of Natural Weathered Spilled Oil, Niger Delta: Compositional Characteristics and Fate of Petroleum Hydrocarbons. Journal of Applied Sciences in Environmental Sanitation, 8 (4): $243-248$

Onyema, O.M. (2012). Source determination and correlation of two oil spill sites using 
geochemical markers. Ph.D. Thesis, University of Port Harcourt, Nigeria.

Oros, D., Collier, R., Simoneit, B. (2007). The extent and significance of petroleum hydrocarbon contamination in Crater Lake, Oregon. Hydrobiologia. 574(1): 85-105.

Osuji, L. C., Uduetok I. A., Ogali, R. E. (2006). Attenuation of petroleum hydrocarbons by weathering: A case study. Chemistry and Biodiversity 3 (4):422-433.

Peters, K. E., Walters, C. C., Moldowan, J. W. (2005). The Biomarker Guide 2nd ed, Cambridge University Press, Cambridge, UK.

Stout, S. A., Liu, B, Millner G.C., Hamlin, D., Healey, E. (2007). Use of chemical fingerprinting to establish the presence of spilled crude oil in a residential area following hurricane Katrina, St. Bernard parish, Louisiana. Environmental Science Technology 41: 7242-7251.

Sun, P., Bao, M., Li, G., Wang, X., Zhao, Y., Zhou, Q., Cao, L. (2009). Fingerprinting and source identification of an oil spill in China Bohai Sea by gas chromatography-flame ionization detection and gas chromatography-mass spectrometry coupled with multi-statistical analyses. Journal of Chromatography A 1216 (5): 830-836.
Tissot B.P., Welte D.H. (1984). Petroleum formation and occurrence, A New Approach to Oil and Gas Exploration. Spinger-Verlag, Berlin.

Wang, Z., Fingas, M. (2003). Development of oil hydrocarbon fingerprinting and identification techniques. Marine Pollution Bulletin 47(9-12): 423-452.

Wang, Z. D., Fingas, M., Blenkinsopp, S., Sergy, G., Landriault, M., Sigouin, L., Foght, J., Semple, K., Westlake, D. W. S. (1998). Oil composition changes due to biodegradation and differentiation between these changes to those due to weathering. Journal of Chromatography A 809: 89-107.

Wang, Z.D., Stout, S.A., Fingas, M. (2006). Forensic Fingerprinting of Biomarkers for Oil Spill Characterization and Source Identification. Environmental Forensics 6: 187-196.

Zabbey, N. (2008). Persistent oil spillage at Bodo creek; unprecedented impacts on ecosystem stability, biodiversity and food security of Ogoni communities. A Report Issued by The Environment and Conservation Program, Centre for Environment, Human Rights and Development (CEHRD), Eleme, Rivers State, Nigeria. 